\title{
The Development of Mathematics Comic Containing Pancasila Values to Develop Character of Elementary School Students: A Case Study of Indonesia
}

\author{
Farid Ahmadi ${ }^{(1)^{*}}$, Rochmad Rochmad $^{(2)}$, Farida Puput Lestari ${ }^{(3)}$, Dewanto Harjunowibowo $^{(4)}$
}

(1) Universitas Negeri Semarang, Indonesia

(2) Universitas Negeri Semarang, Indonesia

(3) Universitas Negeri Semarang, Indonesia

(4) Universitas Sebelas Maret, Indonesia

*Correspondence to: farid@mail.unnes.ac.id

\begin{abstract}
The present research focuses on developing mathematics comic as a teaching material that integrates the moral value of discipline and hard work for elementary school students. This character-building comic development method was made based on the ADDIE model, which includes analysis, design, development, implementation, and evaluation. Twenty-nine grade four students were recruited as samples, consisting of a small group of students in the limited trial group and a big group of students in the field trial group. The data collection technique used was a questionnaire. The development of mathematics comic teaching material containing discipline and hard work character-building has successfully resulted in a comic that met the feasibility standards. The field trial showed a significant increase of 0.76 and 0.74 in students' character development in terms of discipline and hard work, respectively. The results indicate the effectiveness of mathematics comics in instilling Pancasila moral values in elementary mathematics teaching in Indonesia.
\end{abstract}

Keywords: comics; character education; development; Pancasila values; teaching material

Recommended citation: Ahmadi, F., Rochmad, R., Lestari, F. P., \& Harjunowibowo, D. (2021). The Development of Mathematics Comic Containing Pancasila Values to Develop Character of Elementary School Students: A Case Study of Indonesia. Journal of Innovation in Educational and Cultural Research, 2(1), 25-34.

\section{INTRODUCTION}

The following writing and referencing rules are to be taken into consideration. In the current decade, many criminal cases and radicalism in society have been allegedly present in the field of education and become the attention of the Indonesian government. The society has suffered a character crisis that contradicts the prevailing beliefs, norms, traditions, and religions in society (Abdullah, 2018). An act of terrorism is one of the results. Therefore, character education is one of the efforts to prepare a quality generation of the nation and to minimize cultural problems and the nation's character crisis (Pertiwi \& Marsigit, 2017). In line with the statement, Dewi and Pertiwi and Marsigit state that an early sustainable character education for students is crucial as an addition to their cognitive ability (Dewi, 2019; Pertiwi \& Marsigit, 2017). Therefore, in addition to improving students' cognitive ability, schools must also be able to build a foundation for students' strong character (Rudyanto \& Retnoningtyas, 2018).

By considering the importance of character education, school as an educational institution must be able to develop learning that can facilitate students to develop good character. It is stated in the Presidential Regulation number 87, 2017 about the Strengthening of Character Education/ Penguatan Pendidikan Karakter (PPK) that PPK is implemented by integrating the values of Pancasila in the intracurricular, co-curricular and extracurricular activities. The values developed in character education are based on religion, Pancasila, culture, and also the goals of national education. Therefore, it is crucial to instill Pancasila values in students as early as possible because those values are one of the sources for character education (Kemendiknas, 2010).

Pancasila is the foundation, ideology, and philosophy of Indonesia, which must be conserved because it can maintain the unity of The Archipelagic State of the Indonesian Republic (Negara Kesatuan Republik Indonesia/NKRI). Nowadays, the younger generation's understanding of the values of Pancasila is declining, so it is essential to revive and intensify efforts to introduce the values of Pancasila, particularly to the younger generation (Chairiyah, 2014). Therefore, the President of Indonesia established an Agency for Pancasila 
Ideology Education (Badan Pembinaan Ideologi Pancasila/BPIP) in 2018 to ensure that the moral values of Pancasila remain deeply rooted in the heart of Indonesian people (BPIP, 2020; RI, 2018).

One of the methods that can be used to implement character education is by integrating character values into all subjects taught at school, including mathematics (Murti et al., 2020; Suyitno et al., 2019). Character values that can be developed in mathematics learning are discipline, honesty, hard work, democracy, creativity, independence, responsibility, and curiosity (Maryati \& Priatna, 2017), cleanliness, and a healthy lifestyle (Harmawati et al., 2020).

Based on the preliminary research through observation and interviews with teachers and students of the elementary school, it was found the leak of discipline and hard work. Many students came late to the class after break time, keep talking when the teacher was explaining a lesson, do not recheck their work, procrastinate to do the work given in class, and take note only when instructed. The integration of character education in mathematics learning was not optimal because teachers had difficulty in delivering character education in teaching. This condition was exacerbated by a lack of teaching materials and media to support the teaching/learning process.

A solution is required to develop the character of students in elementary schools. One of the steps that can be taken is by making impressive teaching materials that fit students' characteristics and contain the values of Pancasila that can develop their character.

Making teaching materials also facilitates students in learning, so they do not need to look for references on the internet, which provide unverified information. Students are accustomed to using information from the internet without reading and analyzing it carefully (Ahmadi et al., 2019) so that it tends to be misleading. Therefore, this teaching material is expected to help students in their learning process.

To make learning efficient, teaching media that is excellent, interactive, and efficient is needed (Ahmadi \& Maharani, 2019). Also, the combination with a learning approach that is appropriate with the material can improve students' achievement (Octaviani, 2017). The selection of suitable learning materials can be based on learning objectives that have been previously formulated to make it easier for students to learn mathematics (Su'udiah et al., 2016).

Teaching materials have varied forms, and one of them is comics. A comic is a literary work illustrated in pictures that have a storyline. The material which is presented in a clear storyline can make it easier to understand (Reilly, 2015; Soedarso, 2015), liked by all age groups (Özdemir, 2017; Wijayanti et al., 2018), stay longer in students' memory and motivate students to learn (Clair, 2018; Saputro \& Soeharto, 2015). Moreover, comics are also valid for improving students' critical thinking skills and shaping their discipline, cooperation, honesty, confidence, and perseverance (Rasiman \& Pramasdyahsari, 2014). Comics can simplify the learning process, particularly in delivering abstract learning concepts into more concrete examples in daily life (Saputro \& Soeharto, 2015). Additionally, the use of comics in mathematics learning in elementary schools has been proven to be able to increase students' character and learning achievement (Buchori \& Setyawati, 2015). Thus, reading comics will be more interesting for students than in reading textbooks (MeiJu et al., 2015).

Mamolo uses digital comics for advanced learning in high school (Mamolo, 2019), but students in elementary schools will have difficulty to use it because not all students have gadgets and they are easily distracted to play. Therefore, as a solution for the absence of moral values in mathematics learning in elementary education, the development of teaching materials in the form of comics that is integrated with the moral values of Pancasila is expected to be able to develop students' character.

\section{METHODS}

\section{Type of Research}

The study was designed as development research that aims to produce a valid and effective product to improve students' character. The product developed in this study was a teaching material in the form of a mathematics comic containing Pancasila values for the fourth-grade elementary students regarding the topic of surface area and area of rectangle and triangle. The research and development model used was the ADDIE model (Branch, 2010) with five stages. 


\section{Participants}

The research and development model used was the ADDIE model (Branch, 2010) with five stages. The subjects of the research consisted of 29 grade four students of SDN Sampangan 02 Semarang, Indonesia. Six students participated in the limited trial, while 23 took part as research subjects in the large scale trial.

\section{Procedures}

Five stages of development were employed in the research, as illustrated in Figure 1.

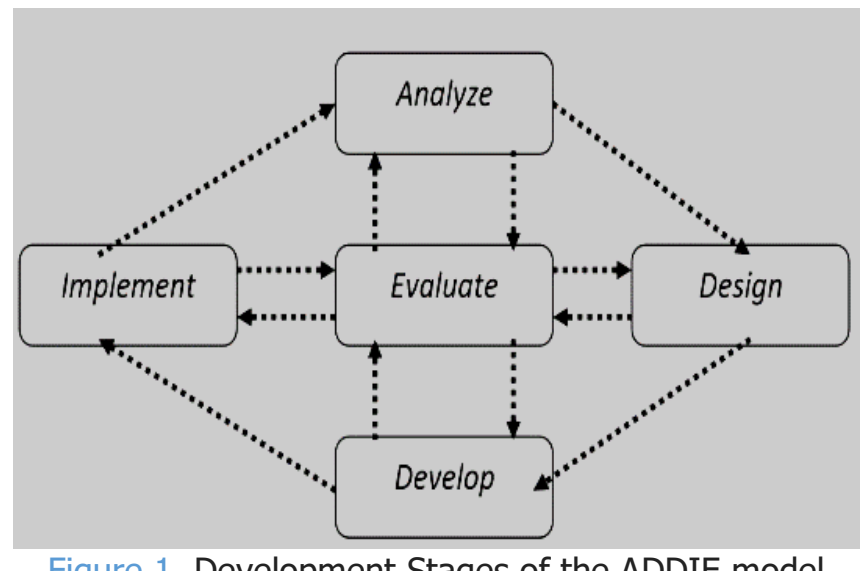

Figure 1. Development Stages of the ADDIE model

The first stage was analysis which included a needs analysis to identify the existing problems that occur in grade four mathematics learning. After that, the researcher conducted a literature review to find solutions for these problems. An in-depth interview was conducted afterward, and questionnaires were distributed to the homeroom teacher and students to identify the appropriate teaching materials needed.

The second stage was designed. The initial step in the design stage was analyzing the Competency Standard and Basic Competency that would be developed in the comic, and then the learning objectives were formulated. In this stage, the researcher also made a feasibility instrument to validate the developed mathematics comic and questionnaires of students' character and response used in the study.

Some consideration in making comics are as the following (Nurhayati et al., 2018): (1) determining the theme of the story; (2) creating the characters; (3) selecting the visual style-for example, cartoon style, semi cartoon style, realism style, and fine art style; (4) making the script; (5) making the rough sketches; (6) coloring; (7) setting the layout; (8) designing the typography; (9) selecting the design.

In the third stage (development), the researcher began to make a mathematics comic to use in teaching, starting from preparing the learning resources, creating the storyline and characters to produce a script. In the next step, the initial sketch was drawn based on the script. After it was completed, it was repaired and colored, and the dialogues in the speech balloons were added digitally.

This mathematics comic was then validated by experts to assess the feasibility in terms of material, language, and graphics. The validation was conducted before the comic was tested. The validation process involved three experts and one elementary school teacher. Criticisms and also suggestions from the validators were used to improve the developed teaching material. The validation results from the experts were analyzed to find out if the teaching material was eligible to proceed to the next stage.

The fourth step was implementation. At this stage, the teaching material was tested by using it in the learning process in the classroom. The trial was conducted twice; a limited scale trial and large scale trial. Students and teacher gave their responses to the use of the comic. If their responses are right, then the large scale trial can be conducted. The data on students' character development were obtained from the questionnaires that were filled out before and after learning using mathematics comic containing Pancasila values.

The last stage was an evaluation to find out whether the product development met the objectives. If it does not achieve the expected goals, then the cycle at the previous stage can be repeated. At this evaluation stage, the researcher analyzed the character development of students before and after using the mathematics comic. Additionally, the improvement made was based on the responses from the teacher and students. An evaluation of the process of developing the teaching material was also conducted as a whole. 


\section{Data Collection Instruments}

The data in this study consisted of the validation results conducted by the material, language, and media experts regarding the feasibility of the product being developed, questionnaire responses about using comics as a teaching material distributed to students and teacher, and questionnaires about students' character trait of discipline and hard work. The data collection instruments used in this study were questionnaires using a Likert scale. The data obtained were quantified and used to determine the quality of the mathematics comic, which included the feasibility and effectiveness of the product.

\section{Data Analysis}

The average percentage of the quantification of the validation results from experts and responses from students and teacher were obtained using the following formula (Damayanti et al., 2018).

$$
x_{i}=\frac{\sum \quad S}{S_{\max }} \times 100 \%
$$

Description: $x_{i}=$ Feasibility score; $\Sigma \mathrm{S}=$ Number of scores

$$
\text { QUOTE } S_{\max } S_{\max }=\text { Maximum score }
$$

After that, the percentage obtained was interpreted for the product feasibility category (Asyhari \& Silvia, 2016), as shown in Table 1. Furthermore, the questionnaire scores obtained were calculated and interpreted into a four-scale score, as shown in Table 2.

Table 1. Product Feasibility Assessment Rubric

\begin{tabular}{cc}
\hline Scores $(\%)$ & Categories \\
\hline $81<$ score $<100$ & Very eligible \\
$61<$ score $<80$ & Eligible \\
$41<$ score $<60$ & Fairly eligible \\
$21<$ score $<40$ & Less eligible \\
$0<$ score $<20$ & Not eligible \\
\hline
\end{tabular}

Table 2. Character Assessment Rubric

\begin{tabular}{cc}
\hline Interval Scores (\%) & Categories \\
\hline $\mathrm{Mi}+1.5 \mathrm{SDi} \leq \mathrm{X} \leq \mathrm{Mi}+3 \mathrm{SDi}$ & Very good \\
$\mathrm{Mi}+0 \mathrm{SDi} \leq \mathrm{X} \leq \mathrm{Mi}+1.5 \mathrm{SDi}$ & Good \\
$\mathrm{Mi}-1.5 \mathrm{SDi} \leq \mathrm{X} \leq \mathrm{Mi}+0 \mathrm{SDi}$ & Fairly good \\
$\mathrm{Mi}-3 \mathrm{SDi} \leq \mathrm{X} \leq \mathrm{Mi}-1.5 \mathrm{SDi}$ & Poor \\
\hline
\end{tabular}

Description: $\mathrm{X}=$ score obtained; $\mathrm{Mi}=0.5 \times$ (maximum score + minimum score);

$\mathrm{SDi}=1 / 6 \times$ (maximum score - minimum score)

\section{RESULT AND DISCUSSION}

The needs analysis carried out in schools through interviews with teachers and giving questionnaires to students and teachers. The results of the interview with the teacher explained that the necessary teaching materials on the learning of mathematics which is integrated with the values of Pancasila to develop the students' character. Teaching materials should contain materials, implementation of materials on the questions from the real-life problem. The presentation of teaching materials should also be using the illustrations in the form of images or stories. The language used in teaching materials is the daily language that is easily understood by students.

Based on the results of the questionnaire analysis of students' needs, it was found that the students liked the cartoon characters, the story suggested to be appointed as the comic is about the daily life, the teaching materials made had various colors, the language used was the daily language with a short discourse and clear so that it is easy for students to understand, the presentation of the material uses an attractive illustration of pictures.

Based on the results of the questionnaire analysis of the teacher's needs, it was found that characters that can be developed through teaching materials include religious, honest, hard work, responsibility, and 
discipline. The story presented in the comic is the daily stories. The presentation of the teaching material using image illustrations with attractive colors. Teaching materials should contain practice questions. The language used is the daily language that easy for students to understand and written by using a font that is easy to read (comic sans). The number of pages on teaching materials is adjusted according to the needs.

The next step was designing the teaching material based on the results of the needs analysis conducted at the beginning. The characters were created in human-shaped cartoon characters using twodimensional plane figures (square, rectangle, triangle, oval, and circle) for the body parts, as shown in Figure 2. Moreover, the learning models and other instruments needed were also provided.
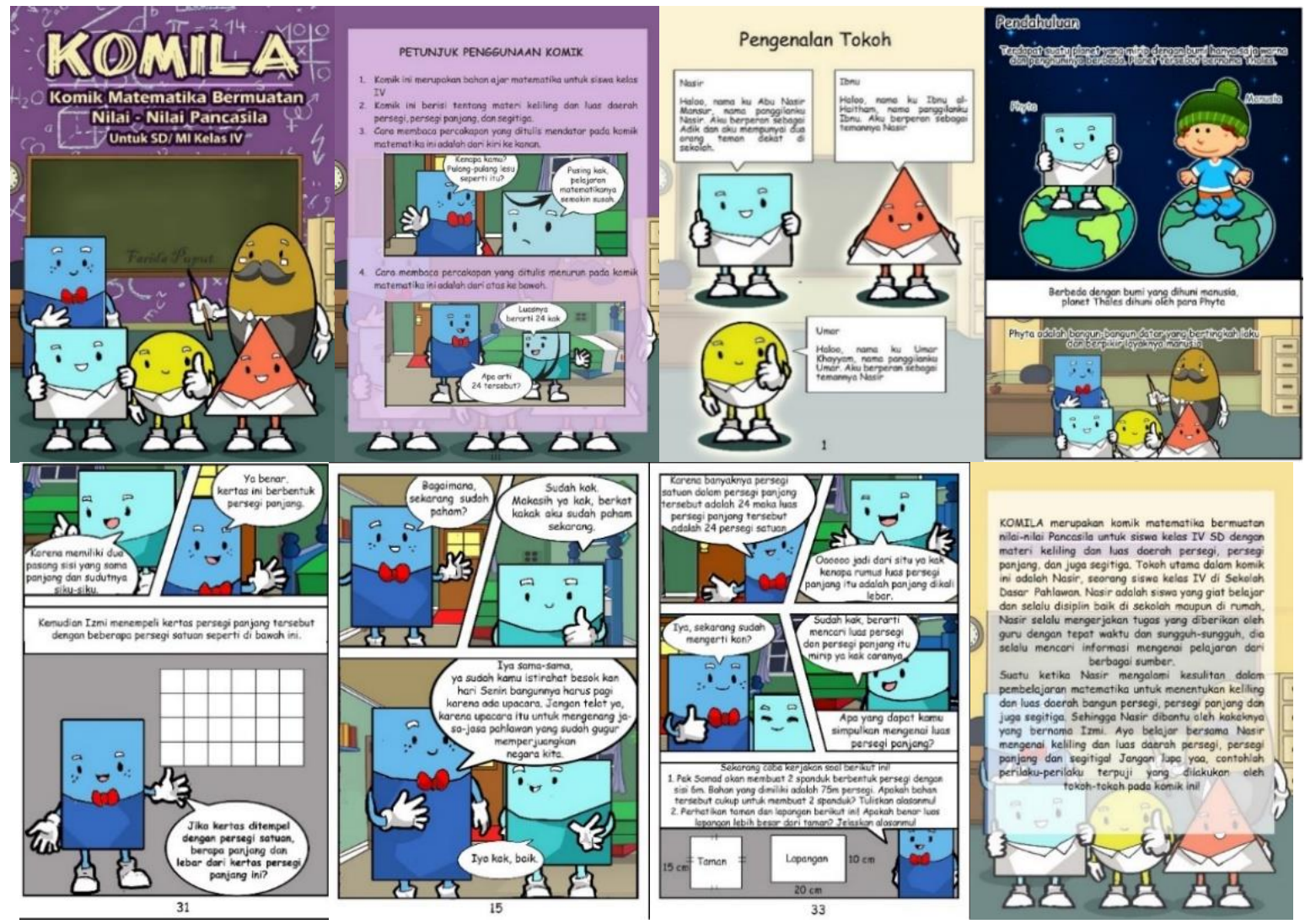

Figure 2. Comics cover and strip

The development stage of the comic was started by composing the storyboard and sketches. The sketches were digitized and colored, and the balloons containing dialogue were added. Coloring and addition of the speech balloon at once with the dialogue done with the Photoshop program. The first stage of coloring is coloring the images with a base color, then applying a gradient color to make the colors look more vivid. After the coloring is finished, the balloons and the text inside are arranged according to the storyline that has been created.

After the comic was completed, it was validated in aspects of material, language, and media to obtain suggestions. The validation scores on average indicated that the comic was very feasible to use. Some suggestions for improvement were taken into consideration, such as strengthening the moral content, fixing the typography, and improving the design of the cover and introduction.

The results of the validation in terms of material aspects are presented in Table 3. It can be seen that the average score for the content, presentation, and the integration of Pancasila values is above $83 \%$, meaning that the comic is very eligible. 
Table 3. Validation Results in Material Aspect

\begin{tabular}{ccc}
\hline Aspects & Percentage & Criteria \\
\hline Content & $81.25 \%$ & Very eligible \\
Presentation & $85 \%$ & Very eligible \\
Integration of Pancasila values & $83.33 \%$ & Very eligible \\
Average & $83.19 \%$ & Very eligible \\
\hline
\end{tabular}

The validation results in the language aspect are presented in Table 4. The assessment aspects focusing on whether the language used is communicative, interactive, and suitable for the development of students show a percentage of above $80 \%$. It means that the language used in the comic is very eligible. However, in terms of whether the language used is direct and standardized, the results show that it is eligible. Therefore, an intensive improvement in these two aspects was needed. On the positive side, the average assessment of the language eligibility is almost $86 \%$ which is very eligible.

Table 4. Validation Results in Language Aspect

\begin{tabular}{ccc}
\hline Aspects & Percentage & Criteria \\
\hline Direct & $67 \%$ & Eligible \\
Communicative & $100 \%$ & Very eligible \\
Interactive & $87.5 \%$ & Very eligible \\
$\begin{array}{c}\text { Suitable with the } \\
\text { development of } \\
\text { students }\end{array}$ & $100 \%$ & Very eligible \\
Standardized & $75 \%$ & Eligible \\
Average & $85.90 \%$ & Very eligible \\
\hline
\end{tabular}

The validation results in the media aspect are presented in Table 5. All aspects such as size, cover design, and content of the comic show a percentage of eligibility above $85 \%$ (very eligible). Moreover, the average score of assessment is $89.01 \%$, which is very eligible. Thus, this comic teaching material is very feasible to be used on a limited and large scale trial.

Table 5. Validation Results in Media Aspect

\begin{tabular}{ccc}
\hline Aspects & Percentage & Criteria \\
\hline Size & $87.50 \%$ & Very eligible \\
Cover design & $89.28 \%$ & Very eligible \\
Content & $90.27 \%$ & Very eligible \\
Average & $89.01 \%$ & Very eligible \\
\hline
\end{tabular}

The product implementation stage was carried out twice, on a limited scale trial and large scale trial. From the results of limited scale trial students gave a good response. The comic then improved according to the teacher's suggestion to add page instructions for use. After that continued at the stage of implementation on a large scale trial.

Based on the data obtained, it can be seen that the students and teacher showed an excellent response to the teaching material used. Responses from the students are presented in Table 6. Almost all aspects receive a perfect score with an average percentage of $91.49 \%$ (very eligible).

Table 6. Students Response

\begin{tabular}{ccc}
\hline Aspects & Percentage & Criteria \\
\hline Presentation & 95.65 & Very eligible \\
Practicality & 85.51 & Very eligible \\
Material & 91.30 & Very eligible \\
Language & 93.48 & Very eligible \\
Average & 91.49 & Very eligible \\
\hline
\end{tabular}

The teacher response to the comic teaching material was far more positive. Table 7 summarizes the teacher's response to the mathematics comic developed. It can be seen that all aspects of the assessment receive a percentage of $100 \%$ (very eligible). From these results, it is clear that the teacher's response to the 
mathematics comic containing Pancasila values is outstanding. Teachers feel that the use of mathematics comics can facilitate the students in learning the material and can be used to maximize the integration of character education in learning mathematics.

\begin{tabular}{ccc}
\multicolumn{3}{c}{ Table 7. Teacher Response } \\
\hline Aspects & Percentage & Criteria \\
\hline Presentation & $100 \%$ & Very eligible \\
Practicality & $100 \%$ & Very eligible \\
Material & $100 \%$ & Very eligible \\
Language & $100 \%$ & Very eligible \\
Average & $100 \%$ & Very eligible \\
\hline
\end{tabular}

After some improvement, the comic was used in the field trial stage. The data obtained from the field test were the teacher and student responses, as well as questionnaires about character distributed before and after the implementation of the comic. The development of students' character using the mathematics comic can be seen in Table 8 and Table 9 for discipline and hard work character traits, respectively. It can be seen that students' discipline and hard work character traits show an increase of $76 \%$ and $74 \%$ respectively. It indicates that the use of the developed mathematics comic teaching material containing Pancasila values can improve students' character significantly.

\begin{tabular}{|c|c|c|c|}
\hline Data & Average & Categories & Gain \\
\hline Before & 10.87 & Good & \multirow{2}{*}{0.76} \\
\hline After & 14.78 & Very good & \\
\hline Data & Average & Categories & Gain \\
\hline Before & 8.35 & Good & 0.74 \\
\hline After & 12.52 & Very good & \\
\hline
\end{tabular}

In the final stage, the evaluation of the teaching material was carried out, and the analysis was conducted based on the previously obtained data. From the field trial, a suggestion to add the back cover of the comic to make it more interesting was received.

The result of needs analysis in the elementary school revealed that the mathematics learning resources containing Pancasila moral values were not available, Asriani et al. (2017) found that books that have been used in schools even though they have met the eligibility criteria for content, presentation, and graphics, are still inadequate in integrating character education.

Also, students lacked interest in reading mathematics books. For these reasons, a mathematics teaching material that teaches discipline and hard work in the form of comics was developed. To attract students' interest to read the comic, popular language that is easy to understand along with stories and pictures were used. As stated by Daryanto (2013), where students usually like books that are pictorial, full of color, and visualized in realistic or cartoon forms. According to Arlyanti et al. (2018), the selection of teaching materials must be adjusted to students' characteristics or level of intellectual development in order to increase creativity and instill good moral values for students.

The researcher then designed the teaching materials according to the results of the needs analysis that had been carried out. Researchers designed learning using a contextual approach to the circumference and surface area of rectangles, rectangles, and triangles for fourth-grade students. Furthermore, the researchers developed mathematics comic teaching materials that had been designed beforehand. After the teaching materials were completed, the researcher gave the teaching materials in the form of mathematics comics to the material experts, linguists, and media experts for validation. Researchers made various improvements to the mathematics comic on the advice of experts so that the resulting product could be even better.

Based on the results of the analysis that has been done, the validation result from the material language, and media experts included in the very eligible category. From the results of this analysis, it can be said that the mathematics comic teaching materials that have been made are in the very eligible category (Asyhari \& Silvia, 2016).

The implementation on a limited scale trial showed that students needed instructions for using the comic in order to help them understand the purpose of making the teaching material (Aina, 2013; Yeboah et 
al., 2019). The students liked and enjoyed this comic very much, with the use of comics can make learning activities more fun and students are more actively engaged in learning to build knowledge and character (Suryatin \& Sugiman, 2019). This condition can lead to an improvement in students' learning interest (Russo et al., 2020) and children's character development.

From the results of the questionnaire that had been analyzed, it was found that the character of discipline and hard work of students before learning using mathematics comic teaching materials containing Pancasila values were in a good category. After using mathematics comic teaching materials that contain Pancasila values, the character of discipline and hard work of students develops into the very good category. These results indicate that the application of comic mathematics teaching materials with the values of Pancasila can improve the students' character of discipline and hard work.

Furthermore, the results of this research are in line with previous studies stating that mathematics comic teaching material developed based on character values can increase students' character (Manalu et al., 2017; Rina et al., 2020), learning motivation, and students' character (Widyawati \& Prodjosantoso, 2015), character and knowledge of elementary school students (Yulianti et al., 2016).

Thereunto, by implementing Pancasila values through the behavior of characters in the comic, it can encourage students to imitate what they read and see. Therefore, these character values can be instilled better in students without making them feel being told to do so (Puspitorini et al., 2014).

\section{CONCLUSION}

This research aims to improve the elementary school students' character trait of discipline and hard work by developing teaching material and integrating the moral values of Pancasila. Based on the results and discussion, it can be concluded that a mathematics comic teaching material containing Pancasila values has been successfully developed and is in accordance with the needs of students and teachers. Based on the results of the validation in material, language and media aspects, this mathematics comic teaching material is very feasible to use in learning mathematics in elementary schools. Besides, the use of mathematics comic teaching material containing Pancasila values has proven that it can significantly improve the students' character trait of discipline and hard work.

\section{REFERENCES}

Abdullah, A. (2018). Cultivating Morals Students through Character Education: A Case Study. Journal of Education and Learning (EduLearn), 12(3), 457-463.

Ahmadi, F., Hapsari, I. P., Rozi, F., \& Bishop, C. (2019). Improving australian students' cognitive critical literacy through e-bipa based on android. International Journal of Innovation, Creativity and Change, 9(5), 119-128.

Ahmadi, F., \& Maharani, S. P. (2019). E-learning based on “Joomla!" to improve the learning results of social studies content in primary school. International Journal of Innovation, Creativity and Change, 5(5), 394-405.

Aina, K. J. (2013). Instructional Materials and Improvisation in Physics Class : Implications for Teaching and Learning. IOSR-Journal of Research \& Method in Education, 2(5), 38-42.

Arlyanti, I., Kosasih, \& Apriliya, S. (2018). Pemilihan Bahan Ajar Cerita Anak berdasarkan Karakteristik Siswa SD. Pedadidaktika: Jurnal Ilmiah Pendidikan Guru Sekolah Dasar, 5(1), 221-231.

Asriani, P., Sa'adijah, C., \& Akbar, S. (2017). Bahan Ajar Berbasis Pendidikan Karakter untuk Siswa Kelas IV Sekolah Dasar. Jurnal Pendidikan - Teori, Penelitian, Dan Pengembangan, 2(11), 1456-1468.

Asyhari, A., \& Silvia, H. (2016). Pengembangan Media Pembelajaran Berupa Buletin dalam Bentuk Buku Saku untuk Pembelajran IPA Terpadu. Jurnal Ilmiah Pendidikan Fisika Al-Biruni, 5(1), 1-13.

BPIP. (2020). BPIP - Badan Pembinaan Ideologi Pancasila.

Branch, R. M. (2010). Instructional design: The ADDIE approach. In Instructional Design: The ADDIE Approach. Springer US.

Buchori, A., \& Setyawati, R. D. (2015). Development Learning Model of Character education through EComic in Elementary School. International Journal of Education and Research, 3(9), 369-386.

Chairiyah. (2014). Revitalisasi Nilai-nilai Pancasila Sebagai Pendidikan Karakter. Jurnal Pendidikan, 1(1), 5462. 
Clair, J. S. (2018). Using Cartoons to Make Connections and Enrich Mathematics. In L. M. Stueve (Ed.), Proceedings of the Interdisciplinary STEM Teaching and Learning Conference (Vol. 2, pp. 45-53).

Damayanti, A. E., Syafei, I., Komikesari, H., \& Rahayu, R. (2018). Kelayakan Media Pembelajaran Fisika Berupa Buku Saku Android pada Materi Fluida Statis. Indonesian Journal of Science and Matematics Education, 1(1), 63-70.

Daryanto, D. (2013). Media pembelajaran: Peranannya sangat penting dalam mencapai tujuan pembelajaran. Gava Media.

Dewi, N. D. (2019). Pengaruh Pendekatan Probing-Prompting Learning (PPL) Terhadap Peningkatan Kemampuan Pemahaman Nilai-Nilai Pancasila. Jurnal Pancasila Dan Kewarganegaraan, 4(1), 34-44.

Harmawati, D., Hasanah, N., Belwawin, S. M., \& Hidayat, S. H. (2020). Developing of an educative comic on the theme of clean and healthy life for grade 2 students of the elementary schools of YPPK Biankuk Merauke. Enfermería Clínica, 30(2), 371-373.

Kemendiknas. (2010). Penguatan Metodologi Pembelajaran Berdasarkan Nilai-Nilai Budaya Untuk Membentuk Daya Saing Dan Karakter Bangsa. In Kemendiknas. BPPPK.

Mamolo, L. A., \& Wang, S. (2019). Development of digital interactive math comics (DIMaC) for senior high school students in general mathematics. Cogent Education, 6(1), 1689639.

Manalu, M. A., Hartono, Y., \& Aisyah, N. (2017). Pengembangan Media Komik Matematika Berbasis Nilai Karakter Pada Materi Trigonometri Di Kelas X SMA Negeri 1 Indralaya Utara. Jurnal Elemen, 3(1), 3548.

Maryati, I., \& Priatna, D. N. (2017). Integrasi Nilai-Nilai Karakter Matematika Melalui Pembelajaran Kontekstual. Jurnal Mosharafa, 6(3), 333-344.

Mei-Ju, C., Yung-Hung, H., \& Ching-Chi, C. (2015). Will Aesthetics English Comic Books Make Junior High School Students Fall in Love with English Reading? Universal Journal of Educational Research, 3(10), 671-679.

Murti, D. K., Gunarhadi, G., \& Winarno, W. (2020). Development of Educational Comic with Local Wisdom to Foster Morality of Elementary School Students: A Need Analysis. International Journal of Educational Methodology, 6(2), 337-343.

Nurhayati, N., Aswar, A., \& Arifin, I. (2018). Komik Sebagai Media Pembelajaran Matematika Bagi Siswa Sekolah Dasar. Jurnal Imajinasi, 2(2), 25-34.

Octaviani, S. (2017). Pengembangan Bahan Ajar Tematik Dalam Implementasi Kurikulum 2013 Kelas 1 Sekolah Dasar. EduHumaniora: Jurnal Pendidikan Dasar Kampus Cibiru, 9(2), 93-98.

Özdemir, E. (2017). Humor in elementary science: development and evaluation of comic strips about sound. International Electronic Journal of Elementary Education, 9(4), 837-850.

Pertiwi, I., \& Marsigit, M. (2017). Implementasi pendidikan karakter dalam pembelajaran matematika SMP di Kota Yogyakarta. Jurnal Riset Pendidikan Matematika, 4(2), 153-165.

Puspitorini, R., Prodjosantoso, A. K., Subali, B., \& Jumadi, J. (2014). Penggunaan Media Komik Dalam Pembelajaran IPA Untuk Meningkatkan Motivasi dan Hasil Belajar Kognitif dan Afektif. Jurnal Cakrawala Pendidikan, 3(3), 413-420.

Rasiman, \& Pramasdyahsari, A. S. (2014). Development of Mathematics Learning Media E-Comic Based on Flip Book Maker to Increase the Critical Thinking Skill and Character of Junior High School Students. International Journal of Education and Research, 2(11), 535-544.

Reilly, E. M. (2015). Superheroes in math class: Using comics to teach diversity awareness. Works and Days, 32(1), 61-74.

RI, M. (2018). Perpres RI No 7 Tahun 2018 (pp. 1-25). Menteri Hukum dan Hak Asasi Manusia Republik Indonesia.

Rina, N., Suminar, J. R., Damayani, N. A., \& Hafiar, H. (2020). Character Education Based On Digital Comic Media. International Journal of Interactive Mobile Technologies (IJIM), 14(3), 107.

Rudyanto, H. E., \& Retnoningtyas, W. A. (2018). Integrasi nilai - nilai karakter melalui pembelajaran matematika di sekolah dasar. Prosiding Konferensi Ilmiah Dasar, 1(7), 34-43.

Russo, J., Bobis, J., Sullivan, P., Downton, A., Livy, S., McCormick, M., \& Hughes, S. (2020). Exploring the relationship between teacher enjoyment of mathematics, their attitudes towards student struggle 
and instructional time amongst early years primary teachers. Teaching and Teacher Education, 88 , 102983.

Saputro, B. H., \& Soeharto, S. (2015). Pengembangan Media Komik Berbasis Pendidikan Karakter Pada Pembelajaran Tematik-Integratif Kelas IV SD. Jurnal Prima Edukasia, 3(1), 61-72.

Soedarso, N. (2015). Komik: Karya Sastra Bergambar. Humaniora, 6(4), 496-506.

Su'udiah, F., Degeng, I., \& Kuswandi, D. (2016). Pengembangan Buku Teks Tematik Berbasis Kontekstual. Jurnal Pendidikan - Teori, Penelitian, Dan Pengembangan, 1(9), 1744-1748.

Suryatin, S., \& Sugiman, S. (2019). Comic Book for Improving The Elementary School Students' Mathematical Problem Solving Skills and Self-Confidence. Jurnal Prima Edukasia, 7(1), 58-72.

Suyitno, H., Rochmad, R., Sugiharti, E., Suyitno, A., \& Yuanbing, G. (2019). Mathematics Learning Which Include with Character Values (Based on Findings at Guangxi Normal University and UNNES). KnE Social Sciences, 213-221.

Widyawati, A., \& Prodjosantoso, A. K. (2015). Pengembangan Media Komik IPA Untuk Meningkatkan Motivasi Belajar dan Karakter Peserta Didik SMP. Jurnal Inovasi Pendidikan IPA, 1(1), 24-35.

Wijayanti, R., Hasan, B., \& Loganathan, R. K. (2018). Media Comic Math Berbasis Whiteboard Annimation dalam Pelajaran Matematika. Jurnal Riset Pendidikan Matematika, 5(1), 53-63.

Yeboah, R., Abonyi, U. K., \& Luguterah, A. W. (2019). Making primary school science education more practical through appropriate interactive instructional resources: A case study of Ghana. Cogent Education, 6(May), 1-14.

Yulianti, D., Khanafiyah, S., \& Sulistyorini, S. (2016). Inquiry-based science comic physics series integrated with character education. Jurnal Pendidikan IPA Indonesia, 5(1), 38-44. 